\title{
Procedure for decreasing the required time for fire resistance of the multistory buildings
}

\section{Procedimento para redução do tempo requerido de resistência ao fogo de edifícios de múltiplos andares}
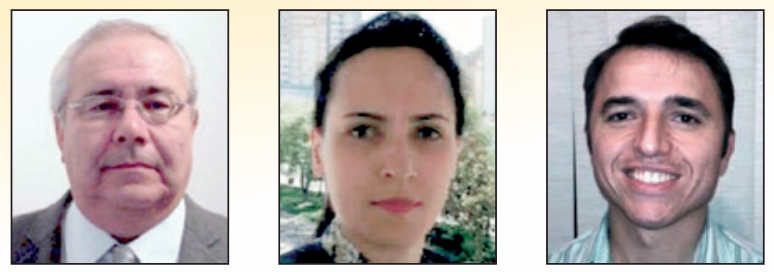

V. P. SILVA a

valpigss@usp.br

C. N. COSTA ${ }^{\circ}$ carlac@fec.unicamp.br

A. R. MELÃO a melao@usp.br

\section{Abstract}

The Brazilian standard ABNT NBR 15200: 2012 details a procedure for decreasing the required time of fire resistance in buildings with good fire safety characteristics. It called equivalent time method. This name can confuse the less habituated to the fire safety area, because the Brazilian procedure is not equal to the original equivalent time method, European. The purpose of this paper is to discuss the equivalent time method, to detail the origins of the Brazilian method and present their limitations no explicit in the Brazilian standard. Some unknown aspects of most researchers or technical means are presented. It should be highlighted the abundant bibliography presented to aid the understanding of a seemingly simple issue, but it incorporates many concepts of fire safety, not always understood by the users.

Keywords: fire, fire resistance, equivalente time method, decresing fire resistance required.

\section{Resumo}

AABNT NBR 15200:2012 detalha um procedimento para a redução do tempo requerido de resistência ao fogo de edificações com boas características de segurança contra incêndio. Ele recebe o nome de método do tempo equivalente. Esse nome pode confundir os menos afeitos à área de segurança contra incêndio, pois o procedimento brasileiro não é equivalente ao MTE original, europeu. O objetivo deste artigo é discorrer sobre o MTE, detalhar as origens do método brasileiro e apresentar suas limitações não explícitas na norma brasileira. Apresentam-se alguns aspectos desconhecidos da maioria dos pesquisadores ou do meio técnico. Destaca-se a revisão bibliográfica apresentada ao longo do texto, para auxiliar a compreensão de um tema aparentemente simples, porém que incorpora diversos conceitos sobre segurança contra incêndio, nem sempre compreendidos pelos usuários.

Palavras-chave: incêndio, TRRF, resistência ao fogo, método do tempo equivalente. 


\section{Introdução}

For more than 8 decades, many researchers have attempted to relate the temperature-time curve of a fire, standardized by various international standards (ASTM E119, 2000; ISO 834, 1990; BS 476, 1987 ) with more realistic curves. More information about the standard-fire (ISO-fire) can be seen in Silva (2012) and Silva (2014).

The EC1 (2002) included the equivalent time method associated with the concept of value of the fire load design, based on the German standard DIN (1987). The Eurocode allows each country to make changes in the method in their local regulations. For example, the UK and Portugal did it.

In Brazil, in the 90s, the Fire Department of Sao Paulo State included in its Technical Instruction (in this text we will simplify by IT) the equivalent time method with several modifications. This IT was published in 2001. In view of the changes, we could not call it of equivalent time method because it could cause confusion to the reader, imagining it to be identical to the method published by the Eurocode. However, by Brazilian tradition is still so called. This is the case of NBR 15200:2012 that use this name.

The aim of this paper is to present the state of the art of the equivalent time method, detailing its formulation and the procedure for reduction the required time for fire resistance that, despite being inspired by the equivalent time method, it had the contribution of other foreign standards and has undergone several modifications.

\section{The equivalent time method}

\subsection{Historic}

In 1928, Ingberg apud HARMATHY (1987) conducted a series

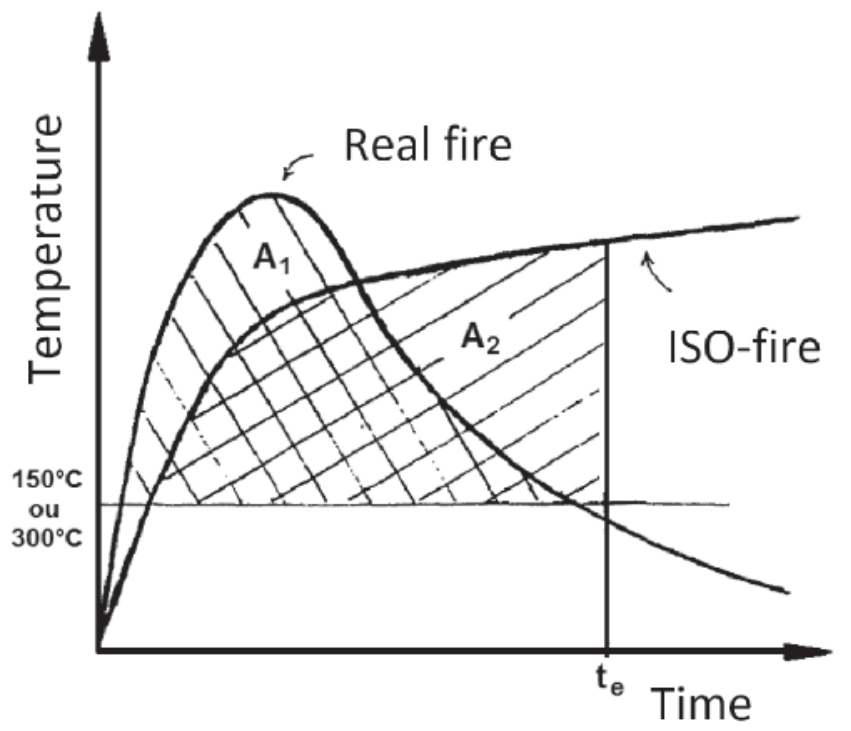

Source: Melão (2016)

\section{Figure 1}

Time equivalent by the concept of the equality of areas under the curves

\section{Table 1}

Relationship between the fire load and time as Ingberg (GEWAIN et al., 2003)

\begin{tabular}{|c|c|}
\hline $\mathbf{q}_{\mathrm{w}}\left(\mathrm{kg}\right.$ of wood $\left./ \mathrm{m}^{2}\right)$ & $\mathbf{t}_{\mathrm{e}}$ (min) \\
\hline 24.4 & 30 \\
\hline 36.6 & 45 \\
\hline 48.8 & 60 \\
\hline 73.2 & 90 \\
\hline 97.6 & 120 \\
\hline 146.5 & 180 \\
\hline 195.3 & 270 \\
\hline 244.1 & 360 \\
\hline 292.9 & 450 \\
\hline
\end{tabular}

of tests at NIST - National Institute of Standards and Technology (then called United States National Bureau of Standards), comparing the areas under actual fire curves with the area under the standard curve, from a predetermined limit temperature (NYMAN, 2002), as shown in Figure 1. He admitted that this area was proportional to the thermal energy given off by the hot gases. The results are shown in Table 1 and Figure 2.

Equation 1 is an adequate approximation to less than 180 min time (Costa, 2008), where $q_{w}$ is the value of fire load density expressed in $\mathrm{kg}$ of equivalent wood per unit area.

$\mathrm{t}_{\mathrm{e}}=1,23 \mathrm{q}_{\mathrm{w}}$

This concept is interesting since the severity of the fire is independent of the structure to be analyzed. That is, two fires with the same severity lead to the same results regardless of the structural element studied.

The Japoneses KAWAGOE; SEKINE (1964) apud (LAW, 1997) followed the same idea from Ingberg, comparing the areas under the curves, but have identified the importance of ventilation (oxygen is the oxidizing material) to determine the temperature of the hot

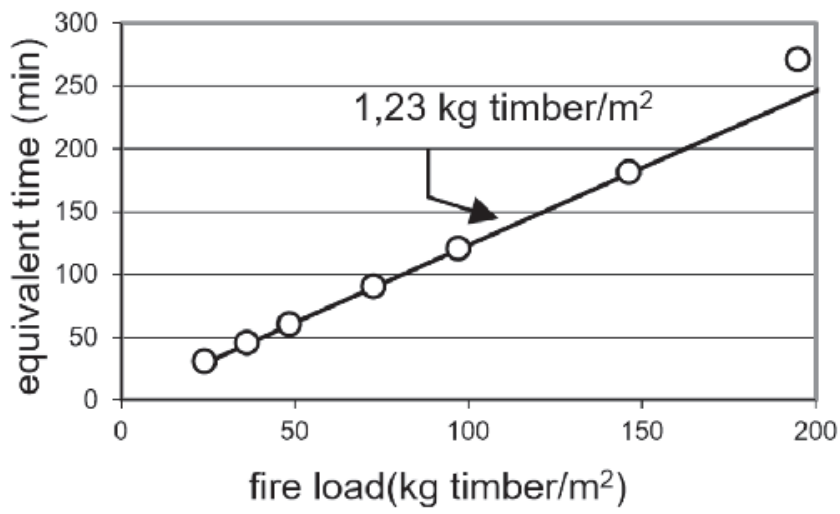

\section{Figure 2}

Relationship between the fire load and time as Ingberg 
gases in the compartment (see item 4 from this text) presenting Equation 2, valid within certain limits of $A_{t} / A_{v} \cdot \sqrt{h_{m}}$.

In Equation 2, $\mathrm{k}_{1}$ is a factor of proportionality, $\mathrm{q}_{\mathrm{fi}}$ is the specific fire load per floor area, $A_{t}$ is the area of all surfaces (floor, ceiling and walls) of the fire compartment and $h_{m}$ is the average height of the openings to the outside of the compartment where oxygen enters.

$\mathrm{t}_{\mathrm{e}}=\mathrm{k}_{\mathrm{l}} \mathrm{q}_{\mathrm{fi}} \cdot\left(\frac{A_{\mathrm{t}}}{A_{\mathrm{v}}} \sqrt{\mathrm{h}_{\mathrm{m}}}\right)^{0,23}$

COOPER, STECKLER (1996) and THOMAS et al. (1997) do not agree with the equivalence between areas, saying they do not represent the thermal energy given off by hot gases, however, we deemed important to mention this concept, as it was a starting point for current fire safety regulations. In MELÃO (2016) a simulation was performed using the equivalent areas, which did not lead to good results.

Law and Petterson apud THOMAS et al. (1997) indicate that the best way to determine the equivalent time is a comparison between the temperatures of structural elements calculated as the two curves as illustrated in Figure 3.

In Figure 3, the "structural element" may be a rebar of concrete element or a steel profile, for example.

In 1971, the British researcher Margaret Law examined the relationship between the standard curve and experimental curves, including the effect of ventilation, but based on Figure 2, and proposed the Equation 3 to determine the equivalent time (HARMATHY, 1987).

$t_{e}=k_{2} \cdot \frac{A_{f}}{\sqrt{A_{v} \cdot\left(A_{t}-A_{f}-A_{v}\right)}} \cdot q_{f i}$

In Equation 3, $k_{2}$ is a factor of proportionality, $A_{v}$ is the area of the openings to the outside of the compartment and $A_{f}$ is the compartment floor area.
The Swedish researcher Pettersson included in 1973, the thermal characteristics of the compartmentation element (see item 4 of this text), in determining the equivalent time (HARMATHY, 1987). Pettersson used natural fire curves theoretically deduced with experimental admeasurements (PETTERSSON et al., 1976) to propose Equation 3.

In Equation 3, $k_{3}$ is a factor of proportionality and $K_{1}$ is a factor related to the physical and thermal characteristics of the compartmentation elements.

$\mathrm{t}_{\mathrm{e}}=\mathrm{k}_{3} \mathrm{~K}_{1} \cdot \frac{\mathrm{A}_{\mathrm{f}}}{\sqrt{\mathrm{A}_{\mathrm{t}} \cdot \mathrm{A}_{\mathrm{v}} \cdot \sqrt{\mathrm{h}}_{\mathrm{m}}}} \cdot \mathrm{q}_{\mathrm{fi}}$

The German standard DIN (1987) includes the influence of the horizontal openings in the ventilation and the level of fire risk, as Equation 4.

$\mathrm{t}_{\mathrm{e}}=\mathrm{K}_{2} \cdot \mathrm{W}_{1} \cdot \mathrm{q}_{\mathrm{fi}}$

In Equation 4, $\mathrm{K}_{2}$ is a factor related to the physical and thermal characteristics of the compartmentation elements, $W_{1}$ is a factor related to the horizontal or vertical ventilation, determined by means of tables provided by DIN (1987) and $\gamma$ is a factor related to the risk.

Reminding that risk is the association between hazard and consequences of a fire, the factor $\gamma$, introduced by DIN (1987), is determined taking into account the dimensions of the building and the presence of active protection. The next version of the DIN, DIN (1998), made some minor modifications (CAJOT et al.) to determine the equivalent time.

The method disclosed in DIN, with adaptations that facilitate its use (e.g., the ventilation effect, determined by tables has been transformed into an equation in EC1) was adopted in EC1 (1995), using Equation 5.

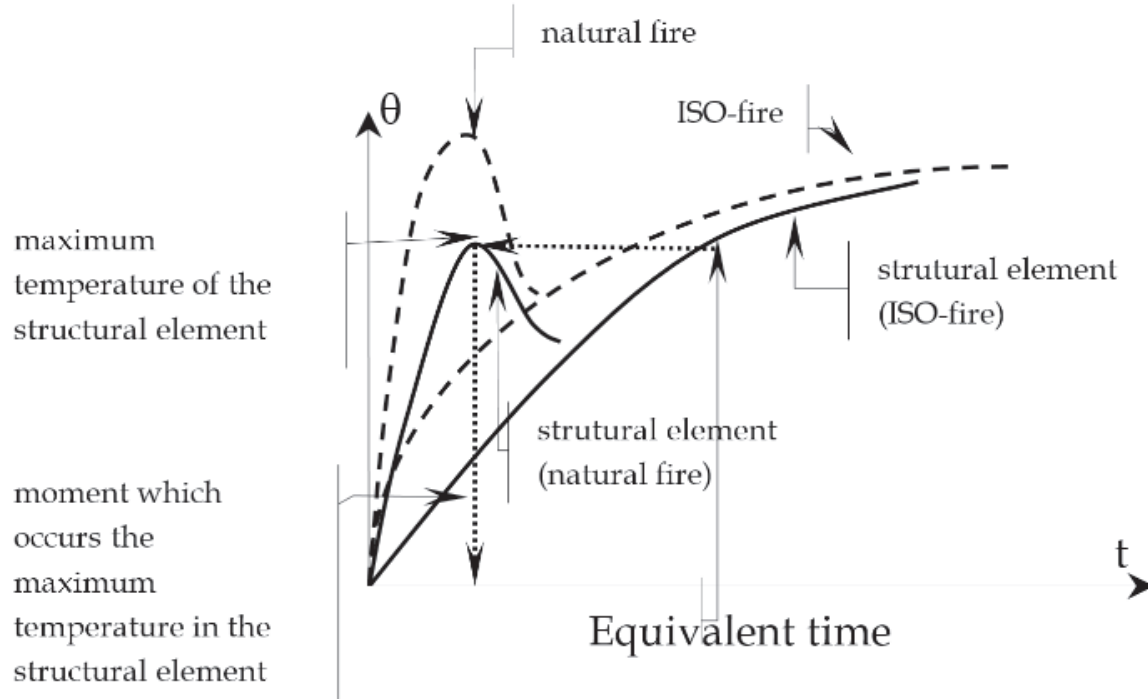

Source: Silva (1997)

Figure 3

Concept of equivalent time 
Table 2

Values of $\gamma_{\mathrm{s} 1}$ (SCHLIECH; CAJOT, 1997)

\begin{tabular}{|c|c|c|c|c|}
\hline \multirow{2}{*}{$\begin{array}{c}\text { Compartment area } \\
\left(\mathbf{m}^{2}\right)\end{array}$} & \multicolumn{4}{|c|}{ Height of the building $(\mathrm{h})$} \\
\cline { 2 - 5 } & $\mathbf{1}$ floor & $\mathbf{2 ~ f l o o r s}$ & $\mathbf{2 ~ t o ~ 1 0 ~ f l o o r s ~}$ & More than 10 floors \\
\hline$\leq 750$ & 1.00 & 1.10 & 1.25 & 1.50 \\
\hline$\leq 2500$ & 1.00 & 1.25 & 1.50 & 2.00 \\
\hline$\leq 5000$ & 1.05 & 1.40 & 1.75 & 2.50 \\
\hline$\leq 10000$ & 1.10 & 1.50 & - & - \\
\hline$\leq 20000$ & 1.20 & 1.60 & - & - \\
\hline
\end{tabular}

Table 3

Values of $\gamma_{\mathrm{s} 1}(\mathrm{IT} 8,2001)$

\begin{tabular}{|c|c|c|c|c|}
\hline \multirow{2}{*}{$\begin{array}{c}\text { Compartment area } \\
\left(\mathbf{m}^{2}\right)\end{array}$} & \multicolumn{4}{|c|}{ Height of the building $(\mathbf{h})$} \\
\cline { 2 - 5 } & One story building & $\mathbf{h} \leq \mathbf{1 2} \mathbf{~}$ & $\mathbf{1 2} \mathbf{~} \mathbf{h} \leq \mathbf{2 3} \mathbf{~}$ & $\mathbf{h}>\mathbf{2 3} \mathbf{~}$ \\
\hline$\leq 750$ & 1.00 & 1.00 & 1.25 & 1.50 \\
\hline$\leq 2500$ & 1.00 & 1.30 & 1.50 & 2.00 \\
\hline$\leq 5000$ & 1.05 & 1.45 & 1.75 & 2.50 \\
\hline$\leq 10000$ & 1.10 & 1.55 & - & - \\
\hline$\leq 20000$ & 1.20 & 1.65 & - & - \\
\hline
\end{tabular}

$$
t_{e}=K W q_{f i, d}
$$

In Equation $5, \mathrm{~K}_{2}$ is a factor related to the physical and thermal characteristics of compartmentation elements, $W$ is related to the ventilation (which depends on the size of the openings) and $\mathrm{q}_{\mathrm{f}, \mathrm{d}}$, the design value of the fire load.

It should be noted in equation recommended by the EC1 (1995), the introduce of the design value of the fire load, $\mathrm{q}_{\mathrm{fid}}$, which is the characteristic value of the fire load determined by measurements or standard tables, multiplied for several factors $\mathrm{Y}$. In EC1 (1995), the only factor presented explicitly was 0.6 when there was sprinklers.
In this part of history, should be cited the publication SCHLIECH; CAJOT (1997). Firstly, because both were the coordinators of the part of the fire of the EC1 and then because Schleich anticipated to SILVA (1997), the main results would be published. It was expected, therefore, that the review of EC1 (1995) follow SCHLEICH; CAJOT (1997).

SCHLEICH; CAJOT (1997) continued the research looking for better explain the factor $y$ and proposed (SILVA, 1997 and SILVA, 2004) that $Y$ were the result of the product $\quad Y_{n}{ }^{\prime} Y_{s 1}{ }^{\prime} Y_{s 2}$.

$\mathrm{Y}_{\mathrm{n}}$ e $\mathrm{Y}_{\mathrm{s} 2}$ will be discussed later in this paper. In this item of the text the interest is on $\mathrm{Y}_{\mathrm{s} 1}$.

$\mathrm{V}_{\mathrm{s} 1}$ is a factor that depends on the consequences of a collapse

\section{Table 4}

Values of $\gamma_{\mathrm{s} 1}($ IT 8,2004$)$

\begin{tabular}{|c|c|c|c|c|c|c|c|}
\hline \multirow{2}{*}{$\begin{array}{c}\text { Compartment } \\
\text { area }\left(\mathbf{m}^{2}\right)\end{array}$} & \multicolumn{7}{|c|}{ Height of the building $(\mathbf{m})$} \\
\cline { 2 - 8 } & $\begin{array}{c}\text { One story } \\
\text { building }\end{array}$ & $\mathbf{h} \leq \mathbf{6}$ & $\mathbf{6}<\mathbf{h} \leq \mathbf{1 2}$ & $\mathbf{1 2}<\mathbf{h} \leq \mathbf{2 3}$ & $\mathbf{2 3}<\mathbf{h} \leq \mathbf{3 0}$ & $\mathbf{3 0}<\mathbf{h} \leq \mathbf{8 0}$ & $\mathbf{h}>\mathbf{8 0}$ \\
\hline$\leq 750$ & 1.00 & 1.00 & 1.10 & 1.20 & 1.25 & 1.45 & 1.60 \\
\hline$\leq 1000$ & 1.05 & 1.10 & 1.15 & 1.25 & 1.35 & 1.65 & 1.85 \\
\hline$\leq 2500$ & 1.10 & 1.25 & 1.40 & 1.70 & 1.85 & 2.60 & 3.00 \\
\hline$\leq 5000$ & 1.15 & 1.45 & 1.75 & 2.35 & 2.65 & 3.00 & 3.00 \\
\hline$\leq 7500$ & 1.25 & 1.70 & 2.15 & 3.00 & 3.00 & 3.00 & 3.00 \\
\hline$\leq 10000$ & 1.30 & 1.90 & 2.50 & 3.00 & 3.00 & 3.00 & 3.00 \\
\hline$\leq 20000$ & 1.60 & 2.80 & 3.00 & 3.00 & 3.00 & 3.00 & 3.00 \\
\hline$\geq 65000$ & 3.00 & 3.00 & 3.00 & 3.00 & 3.00 & 3.00 & 3.00 \\
\hline
\end{tabular}


Table 5

Values of $\mathrm{K}$ in function of the compartmentation element thermal inertia (EC1, 2002)

\begin{tabular}{|c|c|}
\hline $\begin{array}{c}\mathrm{b}=\sqrt{\rho \cdot \mathrm{c} \cdot \lambda} \\
\left(\mathrm{J} / \mathrm{m}^{2} \cdot \mathbf{s}^{1 / 2} \cdot{ }^{\circ} \mathrm{C}\right)\end{array}$ & $\mathrm{K}\left(\min \cdot \mathrm{m}^{2} / \mathrm{MJ}\right)$ \\
\hline$b>2500$ & 0.040 \\
\hline $720 \leq b \leq 2500$ & 0.055 \\
\hline$b<720$ & 0.070 \\
\hline
\end{tabular}

\section{Table 6}

Values of " $M$ " in function of the structural material (EC1, 2002)

\begin{tabular}{|c|c|}
\hline Material da estrutura & M \\
\hline Reinforced concrete & 1,0 \\
\hline Steel without fire protecion & 1,0 \\
\hline Steel with fire protection & $13,7 \times \mathrm{V}$ \\
\hline $\begin{array}{c}\text { Composite structures, } \\
\text { wood, structural masonry }\end{array}$ & Not applied \\
\hline
\end{tabular}

(EC1, 1995), according SCHLEICH; CAJOT (1997) must comply with Table 2.

As already mentioned, the Fire Department of São Paulo included the equivalent time method in Technical Instruction $n \# 8$ of 2001, based on EC1 (1995) updating the procedure based on SCHLEICH; CAJOT (1997). The first author of this work made this suggestion to the CB. Two aspects should be highlighted. The first is that the Fire Department decided to employ the equivalent time method, however, imposed a maximum reduction of $30 \mathrm{~min}$ in the required time for fire resistance recommended by Technical Instruction n\# 8 and, the other, is that the Fire Department use the Table 2 proposed by SCHLIECH; CAJOT (1997), but transformed it in the Table 3 (VARGAS, SILVA, 2005).

The alteration of some values and exchange the number of floors to height in meters did not cause large modification in results, however, it is noted that the line corresponding to time instead of absolute values, was included the symbol " $£$ " meaning that is not allowed interpolation and, as a consequence, depending on the level that is the compartment, there will be jumps in the results, making them unrealistically. This was solved later with the change of the factor gs 1 from table to Equation 12.

SCHLIECH; CAJOT (1997) also reported that Equation 5 had good results for concrete and steel coated, but not for steel without fire protection. Prestressed concrete, wood and masonry were not mentioned in this publication.

\subsection{The equivalent time method based on EC1 (2002)}

After SCHLEICH; CAJOT (1997), these authors researched more about the subject and EC1 (2002) was not published exactly as described in SCHLEICH; CAJOT (1997). The Equation 5 was transformed in Equation 6.
$t_{e}=K W q_{f i, d} M$

$\mathrm{W}=\left(\frac{6}{\mathrm{H}}\right)^{0,3}\left[0,62+\frac{90\left(0,4-\frac{\mathrm{A}_{\mathrm{v}}}{\mathrm{A}_{\mathrm{f}}}\right)}{1+12,5\left(1+10 \frac{\mathrm{A}_{\mathrm{v}}}{\mathrm{A}_{\mathrm{f}}}\right) \cdot \frac{\mathrm{A}_{\mathrm{h}}}{\mathrm{A}_{\mathrm{f}}}}\right] \geq 0,5$

Equation 7 has the following limits of validity: $W \geq 0.5 ; 0,025 \leq A v$ / Af $\leq 0.25$ and $12,5\left[1+10\left(A_{v} / A_{f}\right)\right] \geq 10$.

In Table 6, $\mathrm{V}=\frac{\mathrm{A}_{\mathrm{t}}}{\mathrm{A}_{\mathrm{v}}} \sqrt{\mathrm{h}}$.

$q_{f i, d}=q_{f i, k} \times \gamma_{n} \times \gamma_{s 1} \times \gamma_{s 2}$

In Equation $8, Y_{n}$ is determined by Equation 9 and the values of $Y_{s 1}$ e $\mathrm{Y}_{\mathrm{s} 2}$, respectively, are determined by Tables 7 and 8 .

Perhaps the most important change in EC1 (2002) was the exclusion of building height increasing the risk of fire, assuming therefore unrestricted reliability in vertical compartmentation.

$\gamma_{\mathrm{n}}=\prod_{1}^{11} \gamma_{\mathrm{ni}}$

\section{Table 7}

Values of $\gamma_{s]}$ in function of the compartment area (EC1, 2002)

\begin{tabular}{|c|c|}
\hline Compartment area $\left(\mathrm{m}^{2}\right)$ & $\gamma_{\mathrm{s} 1}$ \\
\hline 25 & 1.10 \\
\hline 250 & 1.50 \\
\hline 2500 & 1.90 \\
\hline 5000 & 2.00 \\
\hline 10000 & 2.13 \\
\hline
\end{tabular}

\section{Table 8}

Values of $\gamma_{\mathrm{s} 2}$ in function of the risk of ativation (EC1, 2002)

\begin{tabular}{|c|c|}
\hline$\gamma_{\mathbf{s} 2}$ & Examples of ocupation \\
\hline 0,78 & Galeria de arte, parque aquático, museu. \\
\hline 1,0 & Escritório, residência, hotel, indústria de papel \\
\hline 1,22 & Indústria de máquinas e motores \\
\hline 1,44 & Laboratório químico, oficina de pintura \\
\hline 1,66 & Indústria de tintas ou explosivos \\
\hline
\end{tabular}


Table 9

Fatores de ponderação das medidas de segurança contra incêndio $(E C 1,2002)$

\begin{tabular}{|c|c|c|c|c|c|c|}
\hline$\gamma_{\mathrm{n} 1}$ & \multicolumn{3}{|c|}{$\gamma_{\mathrm{n} 2}$} & $\gamma_{\mathrm{n} 3}$ & $\gamma_{\mathrm{n} 4}$ & $\gamma_{n 5}$ \\
\hline \multicolumn{4}{|c|}{ Chuveiros automáticos } & \multirow{2}{*}{\multicolumn{3}{|c|}{ Detecção automática }} \\
\hline \multirow[b]{2}{*}{ Existe } & \multicolumn{3}{|c|}{ Suprimentos de água independentes } & & & \\
\hline & 0 & 1 & 2 & Calor & Fumaça & $\begin{array}{l}\text { Transmissão } \\
\text { automática }\end{array}$ \\
\hline $0,61\left(^{*}\right)$ & 1,0 & 0,87 & 0,7 & $0,87\left(^{*}\right)$ & $0,73\left(^{*}\right)$ & $0,87\left(^{*}\right)$ \\
\hline
\end{tabular}

\begin{tabular}{|c|c|c|c|c|c|}
\hline$\gamma_{n 6}$ & $\gamma_{\mathrm{n} 7}$ & $\gamma_{n 8}$ & $\gamma_{n 9}$ & $\gamma_{\mathrm{n} 10}$ & $\gamma_{n 11}$ \\
\hline \multicolumn{2}{|c|}{ Brigada contra incêndio } & \multirow{2}{*}{$\begin{array}{l}\text { Rotas de fuga } \\
\text { (existe e é } \\
\text { desobstruída) }\end{array}$} & \multirow{2}{*}{$\begin{array}{l}\text { Escada } \\
\text { pressurizada }\end{array}$} & \multirow{2}{*}{$\begin{array}{l}\text { Exaustão de } \\
\text { fumaça nas } \\
\text { escadas }\end{array}$} & \multirow{2}{*}{$\begin{array}{c}\text { Dispositivos de } \\
\text { combate }\end{array}$} \\
\hline Interna & Externa & & & & \\
\hline $0,61\left(^{*}\right)$ & $0,78\left(^{*}\right)$ & $\begin{array}{l}\text { Sim }-1,0 \\
\text { Não }-1,5\end{array}$ & $\operatorname{Sim}-0,9\left(^{*}\right)$ & $\begin{array}{l}\text { Sim }-1,0 \\
\text { Não }-1,5\end{array}$ & $\begin{array}{l}\text { Sim }-1,0 \\
\text { Não }-1,5\end{array}$ \\
\hline$\left(^{*}\right)$ na ausênci & & & & & \\
\hline
\end{tabular}

In Equation $9, \mathrm{~V}_{\mathrm{ni}}$ are factors related to safety measures against fire as shown in Table 9.

For characteristic value of the fire load density the EC1 (1995) recommends the Table 10.

\section{Brazilian procedure to reduce the required time for fire resistance}

LAW (1997) concludes that the methods of equivalent time presented so far, and even the Eurocode, are not satisfactory and need to be further evaluated.

The Eurocode allows each country to adapt the national standard to their reality. For example, in the case of the equivalent time method, the Portuguese and British versions of the EC1 have different forms of the equivalent time method. In the Portuguese version (EUROCÓDIGO 1, 2010), $g_{n}{ }^{\prime} g_{s 1}{ }^{\prime} g_{s 2}=1$. The version of

\section{Table 10}

Carga de incêndio específica em $\mathrm{MJ} / \mathrm{m}^{2}$ $(E C 1,2002)$

\begin{tabular}{|c|c|c|}
\hline Ocupação & Média & $80 \%$ fráctil* \\
\hline Residência & 780 & 948 \\
\hline Hospital (quarto) & 230 & 280 \\
\hline Hotel (quarto) & 310 & 377 \\
\hline Biblioteca & 1500 & 1824 \\
\hline Escritório & 420 & 511 \\
\hline Escola (sala de aula) & 285 & 347 \\
\hline Shopping Center & 600 & 730 \\
\hline Teatro/cinema & 300 & 365 \\
\hline Área de embarque & 100 & 122 \\
\hline
\end{tabular}

Eurocode 1 published in UK, BS (2007), extends the use of the method of time equivalent to all structural materials and includes the height of the building in risk analysis, among other details.

In Brazil, ABNT NBR 15200:2012, ABNT NBR 14323:2013 and technical instructions of the Fire Department from several states, present a procedure to reduce the required time for fire resistance in buildings with good features of fire safety. Although it is called of equivalent time method, it is not the original method from Eurocode, but a procedure that takes advantage of the formulation presented in several international standards and publications.

Remembering that the Technical Instruction CB-02-33 of 1994 allowed reducing in 30 minutes the required time for fire resistance to buildings with sprinklers, the new procedure was a major breakthrough. On one hand, the sprinklers may not be sufficient to ensure safety, on the other, buildings without sprinklers may be safe. With this objective, in 2001, the IT 8 of the Fire Department of Sao Paulo State included the method of equivalent time with several modifications from the original one. The NBR 15200:2012 and NBR 14323:2013 included in their texts that procedure, still calling of equivalent time method.

Now we will detail the procedure recommended by ABNT NBR 15200: 2012.

The required time for fire resistance of structural elements of reinforced concrete in each compartment can be determined by Equation 10, but cannot be reduced more than $30 \mathrm{~min}$ from the required time for fire resistance given in Table A. 1 of ABNT NBR 14432: 2001 or those required by the technical instructions of the Fire Department.

$t_{e}=0,07 \times q_{f i, k} \times W \times \gamma_{n} \times \gamma_{s 1} \times \gamma_{s 2}$

In Equation 10, the value 0.07 is the maximum value of $\mathrm{K}$ factor related to physical and thermal characteristics of the compartmentation elements shown in Table 5. The value of $\mathrm{q}_{\mathrm{f}, \mathrm{k}}$ can be determined by local measurements or use standardized values as ABNT NBR 14432:2001 or technical instructions of the Fire Department. Some 
values are shown in Table 11. W follows the same Equation 7, disregarding horizontal openings, hence, Equation 11.

$W=\left(\frac{6}{H}\right)^{0,3}\left[0,62+90\left(0,4-\frac{A_{v}}{A_{f}}\right)\right] \geq 0,5$

With the limit $0,025 \leq \mathrm{Av} / \mathrm{Af} \leq 0,30$

The upper limit of Av / Af was increased in the Brazilian standard in view the graph shown in Figure 4.

Table 11 from of IT 14 (2011) is based on the ABNT NBR 14432:2001,

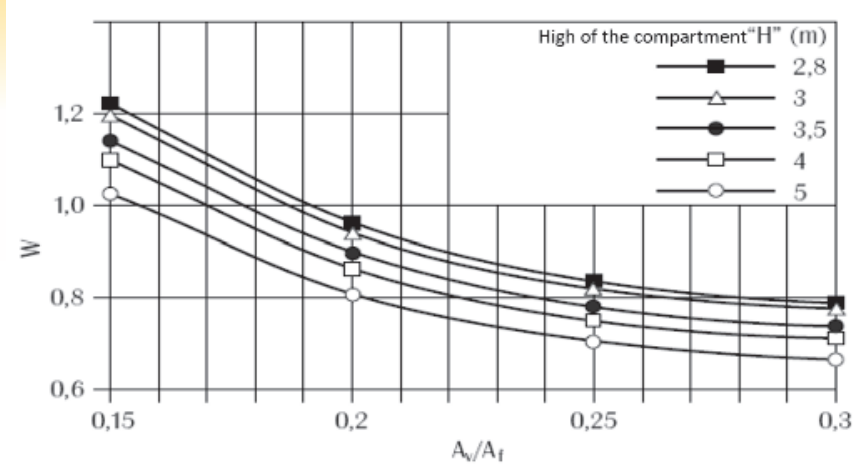

Source: Silva (2012)

Figure 4

Values of $\mathrm{H}$ in function of the ventilation $\mathrm{A}_{v} / \mathrm{A}_{\mathrm{f}}$ and compartment height $\mathrm{H}$

Table 11

Valores de cargas de incêndio específicas (IT14, 2011)

\begin{tabular}{|c|c|c|}
\hline Ocupação/uso & Descrição & Filler \\
\hline Residencial & Apartamentos, casas térreas, sobrados, pensionatos & 300 \\
\hline Serviços de hospedagem & Hotéis, motéis, apart-hotéis & 500 \\
\hline \multirow{7}{*}{ Comercial varejista } & Automóveis & 200 \\
\hline & Drogarias & 1000 \\
\hline & Livrarias & 1000 \\
\hline & Lojas de departamentos (shopings) & 800 \\
\hline & Papelarias & 700 \\
\hline & Supermercados (vendas) & 600 \\
\hline & Tapetes & 800 \\
\hline \multirow{5}{*}{$\begin{array}{c}\text { Serviços } \\
\text { profissionais, } \\
\text { pessoais e técnicos }\end{array}$} & Agências bancárias & 300 \\
\hline & Agências de correios & 400 \\
\hline & Escritórios & 700 \\
\hline & Oficinas elétricas & 600 \\
\hline & Oficinas mecânicas & 200 \\
\hline \multirow{3}{*}{$\begin{array}{l}\text { Educacional e } \\
\text { cultura física }\end{array}$} & Academias & 300 \\
\hline & Creches & 300 \\
\hline & Escolas em geral & 300 \\
\hline \multirow{7}{*}{ Locais de reunião pública } & Bibliotecas & 2000 \\
\hline & Cinemas ou teatros & 600 \\
\hline & Clubes sociais, boates & 600 \\
\hline & Estações, terminais de passag. & 200 \\
\hline & Igrejas & 200 \\
\hline & Museus & 300 \\
\hline & Restaurantes & 300 \\
\hline \multirow{2}{*}{ Serviços automotivos } & Estacionamentos & 200 \\
\hline & Oficinas & 300 \\
\hline \multirow{5}{*}{$\begin{array}{c}\text { Serviços de saúde } \\
\text { e institucionais }\end{array}$} & Asilos & 350 \\
\hline & Clínicas e consultórios médicos ou odontológicos & 300 \\
\hline & Hospitais & 300 \\
\hline & Presídios & 200 \\
\hline & Quartéis & 450 \\
\hline
\end{tabular}


Table 12

Fator de ponderação $\gamma_{n}$ das medidas

de segurança contra incêndio

(ABNT NBR 15200:2012; IT8, 2011)

\begin{tabular}{|c|c|c|}
\hline \multicolumn{3}{|c|}{ Valores de $\gamma_{n 1}, \gamma_{n 2}$ e $\gamma_{n 3}$} \\
\hline $\begin{array}{c}\text { Existência } \\
\text { de chuveiros } \\
\text { automáticos } \\
\gamma_{\mathrm{n} 1}\end{array}$ & $\begin{array}{c}\text { Brigada contra } \\
\text { incêndio } \\
\gamma_{\mathrm{n} 2}\end{array}$ & $\begin{array}{c}\text { Existência } \\
\text { de detecção } \\
\text { automática } \\
\gamma_{\mathrm{n} 3}\end{array}$ \\
\hline 0,60 & 0,90 & 0,9 \\
\hline
\end{tabular}

which in turn followed the Austrian standards TRVB A-100 (1987) and TRVB A-126 (1987). These Austrian standards were based on Gretener method (SIA, 1996).

The factor $\gamma_{n}$ is determined by Equation 9, but in a simplified way, as can be seen in Table 12. In the absence of any means of protection, indicated in Table 12, adopt $Y_{n}$ equal to 1.

The factor $\mathrm{Y}_{\mathrm{s} 1}$ is determined by Equation 12, where $A_{f}$ is the floor area of the compartment in square meters, and $\mathrm{h}$ is the distance between the highest habitable floor and the lowest (either underground) of the building in meters. For $\mathrm{g}_{\mathrm{s} 1}<1$, it should be adopted $g_{\mathrm{s} 1}=1$ and $\mathrm{g}_{\mathrm{s} 1}>3$, can adopt $\mathrm{g}_{\mathrm{s} 1}=3$.

Given that the final version of EC1 (2002) the influence of height had been removed from the equivalent time method and the tables recommended in IT8 (2001 and 2004) had unwanted and unrealistic discontinuities, Equation 12 was created based on the following principles: maintain the influence of the height; slightly reduce the influence of height, do not to differ much from the results obtained with the method recommended by IT8 $(2001,2004)$ that was based on proposals from the Eurocode review; adopt a limit value slightly higher than the previous, 2.5 ; don't have discontinuities and be easy to use. Although there are some differences in the results obtained by Equation 12 and tables of IT 8, the final values of the required time for fire resistance of buildings are very similar as shown in SILVA (2008).

$\gamma_{\mathrm{s} 1}=1+\frac{\mathrm{A}_{\mathrm{f}} \cdot(\mathrm{h}+3)}{10^{5}}$

The $g_{\mathrm{s} 2}$ factor has the same function as that recommended by EC1 (2002), i.e., consider the risk of fire activation. According SCHLEICH; CAJOT (1997), the factor $g_{\mathrm{s} 2}$ means the hazard of fire activation and was originated in Gretener method for analysis of fire risk in buildings, published in the SIA-81 (1996). The EC1 (2002) does not provide sufficient examples of buildings. Then Table 9 was completed based on Gretener method (SIA 81, 1996), generating the Table 13.

Tables 11 and 13 originated in Gretener method. In 1960, Max Gretener engineer, director of Fire Protection Association, Switzerland, began studies on calculating the risk of fire in industries and large buildings. Their method, published in 1965, aimed to meet the needs of insurance companies. In 1968 the Swiss Fire Department proposed to adopt the same method also to assess the means of fire protection of buildings. In 1984, SIA (Société Suisse des Ingénieurs et des Architectes) published the SIA-81 document "Method of assessment of fire risk," based on the Gretener work and reviewed by a group of experts from private and state insurance companies and SIA. This group has adapted the method to the then knowledge and Swiss and international experience. In December of 1996, SIA-81 was revised and updated, SIA 81 (1996). According Cajot et al. (no date) the results of this work are scientifically demonstrable, although not all have been demonstrated. In addition to the limitations already mentioned, to safety side, also was imposed that time determined by the method presented can not be less than $15 \mathrm{~min}$ and $\mathrm{q}_{\mathrm{fi}, \mathrm{k}} \mathrm{Y}_{\mathrm{n}} \mathrm{Y}_{\mathrm{s}} \geq 300 \mathrm{MJ} / \mathrm{m}^{2}$

\section{Compartimentation}

It notes that the procedure described in item 3 of this text is to be used for each compartment. So, the concept of compartment must be very clear to the user.

Compartment is the building or part thereof, comprising one or more rooms, spaces or floors, built to prevent the spread of fire from inside to outside of the boundaries, including the spread between adjacent buildings, where applicable. Compartmentation elements are constructive elements which seal the compartment and must have thermal insulation, integrity and structural stability. The horizontal compartmentation is that which prevents the horizontal spread between compartments on the same floor. It limits the spread of fire, restricting the losses and facilitating the activity of fire fighting. The IT9 (2011) limits the maximum areas for enclosures (horizontal compartmentation), depending on the use and height of the building

The vertical compartmentation is that which prevents the vertical spread of gases or heat to a floor immediately above. It is one of

\section{Table 13}

Valores de $\gamma_{s 2}$ em função do risco (r) de ativação do incêndio (ABNT NBR 15200:2012; IT8, 201 1)

\begin{tabular}{|c|c|r|}
\hline$\gamma_{s 2}$ & $\mathbf{r}$ & Exemplos de ocupação \\
\hline 0,85 & Pequena & Escola, galeria de arte, parque aquático, igreja, museu \\
\hline 1,0 & Normal & $\begin{array}{r}\text { Biblioteca, cinema, correio, consultório médico, escritório, farmácia, frigorífico, hotel, } \\
\text { livraria, hospital, laboratório fotográfico, indústria de papel, oficina elétrica ou mecânica, } \\
\text { residência, restaurante, supermercado, teatro, depósitos (produtos farmacêuticos, bebidas } \\
\text { alcoólicas, venda de acessórios de automóveis) e depósitos em geral }\end{array}$ \\
\hline 1,2 & Média & Montagem de automóveis, hangar, indústria mecânica \\
\hline 1,5 & Alta & Laboratório químico, oficina de pintura de automóveis \\
\hline
\end{tabular}


the most effective measures for fire safety. It is also essential for the calculation of structures in fire.

The vertical compartmentation includes: facade with beam-parapet or marquise, emergency stairs enclosure, slabs with a minimum thickness in order to respect insulation and integrity and sealant (firestops) to seal any vertical connection between floors, such as passage pipes, ducts, shafts etc.

As the law of the São Paulo (SP 2011), the vertical compartmentation is required for residential buildings, offices or hotels and other occupations, for fire heights exceeding $12 \mathrm{~m}$, except for hospitals where the minimum height is $6 \mathrm{~m}$. Further details and requirements for compartmentalization can be seen in the technical instructions of the fire departments or SILVA (2014).

Another important aspect is the distance between facades. This distance must be calculated in such a way as to prevent the passage by radiation from a possible fire of a facade to another in another building, or of the same building (NFPA, 2012; IT7, 2011; SILVA, 2012; SILVA, 2014 ). If this distance is less, the compartment will be extended to another building or another floor of the same building.

In short, to correctly apply the procedure reducing the required time for fire resistance must be checked several aspects of architecture and not only apply Equation 10 .

\section{Partial factors}

When using a method of risk assessment, analyzing a modeling fire or any other procedure related to fire, partial factors of safety should be introduced, as is common in structural engineering. In Brazil, the partial factors for such studies are not standardized, except for the reduction procedure of required time for fire resistance, also known as the equivalent time method. While there is not a more accurate research on this, the authors recommend following the partial factors ( $\mathrm{y}$-factors) of the equivalent time method.

It should be noted that the safety introduction for the equivalent time method is not restricted to $Y_{n}, Y_{s 1} e Y_{s 2}$. The restriction to limit the reduction to $30 \mathrm{~min}$ in relation to the required time for fire resistance tabulated (here called RFtab) should also be considered. Thus, the required time for fire resistance, including the equivalent time method and this restriction can be rewritten as Equation 12, where $t_{e}$ is given by Equation 10 and $F$ is an adjustment factor to take account the maximum reductor of $30 \mathrm{~min}$.

$\mathrm{RF}=\mathrm{t}_{\mathrm{e}} \times \mathrm{F}$

The procedure for reducing the required time for fire resistance can be, analytically, interpreted as follows:

if $\mathrm{t}_{\mathrm{e}} \leq \mathrm{RF}_{\mathrm{tab}}-30 \mathrm{~min}, \mathrm{RF}=\mathrm{RF}_{\mathrm{tab}}-30 \mathrm{~min}$

if $R F_{\text {tab }}-30$ min $<t_{e} \leq R F_{\text {tab }}, R F=t_{e}$

if $\mathrm{t}_{\mathrm{e}}>\mathrm{RF}_{\mathrm{tab}}, \mathrm{RF}=\mathrm{RF}_{\mathrm{tab}}$.

From these considerations, are obtained:

if $\mathrm{t}_{\mathrm{e}} \leq \mathrm{RF}-30 \mathrm{~min}, \mathrm{~F}=\frac{\mathrm{RF}_{\mathrm{tab}}-30 \mathrm{~min}}{t_{e}}$

if $\mathrm{RF}-30 \mathrm{~min}<\mathrm{t}_{\mathrm{e}} \leq \mathrm{RF}, \mathrm{F}=1$

if $\mathrm{t}_{\mathrm{e}}>\mathrm{RF}, \mathrm{F}=\frac{\mathrm{RF}_{\mathrm{tab}}}{t_{e}}$
For the reduction procedure of the required time for fire resistance is irrelevant employ the F-factor or the Equation 10, taking care to limit the reduction in $30 \mathrm{~min}$. However, other methods, for example, use a fire temperature-time curve with more realistic shape such the parametric curves EC1 (2002), using the factor F, it means that we will be keeping the same level of safety of the only method standardized in Brazil.

\section{Conclusions}

In this paper the historical evolution of the equivalent time method was presented. The current method of equivalent time presented in Eurocode is difficult to be accepted by society because it does not consider the height of the building. In Brazil was created a method, which despite being called equivalent time method is not the original equivalent time method but a consensual procedure enshrined in standards and legislation which allows a reduction of up to 30 minutes of required time for fire resistance tabulated by Technical Instructions of fire Brigades, for buildings with good safety features fire. The origin of the Brazilian formulation, including limits and comments were also presented. It was remembered that not just use the presented formulation, but also to examine whether the architectural solution allows the use of such formulation. Finally, the safety introduction in the Brazilian procedure was analyzed and was suggested that while there is no Brazilian standard for partial factors, the safety level of the Brazilian procedure be used for analysis in fire safety, especially in fire models.

\section{Acknowledgments}

The authors thank FAPESP-the São Paulo Research Foundation, CAPES-Coordination for the Improvement of Higher Education Personnel and CNPq - the Brazilian National Council of Scientific and Technological Development.

\section{Referências bibliográficas}

[1] AMERICAN SOCIETY TESTING AND MATERIALS. Standard test methods for fire tests of building construction and materials. ASTM E119-00a. ASTM. Philadelphia, 2000.

[2] ASSOCIAÇÃO BRASILEIRA DE NORMAS TÉCNICAS. NBR 15200: Projeto de estruturas de concreto em situação de incêndio. Rio de Janeiro, 2012.

[3] ASSOCIAÇÃO BRASILEIRA DE NORMAS TÉCNICAS. NBR 14323: Projeto de estruturas de aço e de estruturas mistas de aço e concreto de edifícios em situação de incêndio. 2013.

[4] ASSOCIAÇÃO BRASILEIRA DE NORMAS TÉCNICAS. Exigências de resistência ao fogo de elementos construtivos das edificações. NBR 14432. Rio de Janeiro, 2001.

[5] BRITISH STANDARDS INSTITUTION. Fire tests on building materials and structures - Part 22: Methods for determination of the fire resistance of non-loadbearing elements of construction. BS 476-22. BSI. London, 1987.

[6] BRISTISH STANDARDS. PD 6688-1-2:2007 Background paper to the UK National Annex to BS EN 1991-1-2. 2007. 
[7] CAJOT, L.-G; SCHLEICH, J.-B.; FONTANA M.; SCHWEPPE H.; KINDMANN R.; KIRCHNER, U. Accidental actions: fire influence of the active fire protection measures. Publications of the Profil ARBED: Luxembourg, [s.d.].

[8] COOPER, L.Y.; STECKLER, K.D. Methodology for Developing and Implementing Alternative Temperature-Time Curves for Testing the Fire Resistance of Barriers for Nuclear Power Plant Applications, NIST. National Institute of Standards and Technology. Gaithersburg. 1996.

[9] COSTA, C. N. Dimensionamento de elementos de concreto armado em situação de incêndio. Tese de doutorado defendido junto à Escola Politécnica. São Paulo, 2008.

[10] DEUTSCHES INSTITUT FÚR NORMUNG. Structural fire protection in industrial buildings. DIN 18230. Part 1: Analytically required fire resistance time. [Translated from the original in German]. Berlin, 1987.

[11] DEUTSCHES INSTITUT FÚR NORMUNG. Structural fire protection in industrial buildings - Part 1: DIN 18230-1. DIN. Berlin, 1998.

[12] EUROPEAN COMMITTEE FOR STANDARDIZATION. EN 1991-1-2: EUROCODE 1: Actions on strutures - Part 1-2: General actions - Actions on strutures exposed to fire. Brussels: CEN, 2002.

[13] EUROPEAN COMMITTEE FOR STANDARDIZATION. EN 1991-1-2: EUROCODE 1: Actions on strutures - Part 2-2: Actions on strutures exposed to fire. Brussels: CEN, 1995.

[14] GEWAIN R. G.; IWANKIW N. R.; ALFAWAKHIRI F. Facts for Steel Buildings - Fire. American Institute of Steel Construction. Chicago, 2003.

[15] HARMATHY, T. Z. On the equivalent fire exposure. Fire and Materials. Vol. 11. NRCC: Ottawa, 1987.

[16] INSTITUTO PORTUGUÊS DE QUALIDADE. NP EN19911-2. Eurocódigo 1: Acções em estruturas-Parte 1-2 Acções Gerais. Acções em estruturas expostas ao fogo. 2010

[17] INTERNATIONAL ORGANIZATION FOR STANDARDZATION. Fire-Resistance Tests - Elements of Building Construction - Part 1.1: General Requirements for Fire Resistance Testing. ISO 834. ISO/TC: Geneva, 1990. [Revision of first edition (ISO 834:1975)]

[18] LAW, M. A review of formulae for T-equivalent. In: INTERNATIONAL SYMPOSIUM NO FIRE SAFETY SCIENCE. Melbourne. Proceedings... Melbourne: IAFSS, 1997.

[19] LIGA FEDERAL DE COMBATE A INCÊNDIO DA ÁUSTRIA - "Brandschutztechnische Kennzahlen verschiedener Nutzungen, Langerungen, Lagergüter" (Parâmetros técnicos relativos à proteção a incêndio para diversas aplicações) -. TRVB A-126. 1987.

[20] LIGA FEDERAL DE COMBATE A INCÊNDIO DA ÁUSTRIA - "Brandschutzeinrichtungen Rechnerischer Nachweis" (Dispositivo de proteção a incêndio. Cálculo) - TRVB A-100. 1987.

[21] MELÃO, A. R. Sobre o dimensionamento de elementos estruturais de aço em situação de incêndio. Dissertação de mestrado apresentada à Escola Politécnica da Universidade de São Paulo. 2016.

[22] NATIONAL FIRE PROTECTION ASSOCIATION - NFPA 80a. Recommended practice for protection of buildings from exterior fire exposures. Quincy. 2012
[23] NYMAN, J. F. Equivalent Fire Resistance Ratings of Construction Elements Exposed to Realistic Fires, Tese (Mestrado), Department of Civil Engineering University of Canterbury Christchurch, New Zealand. 2002

[24] PETTERSSON, O.; MAGNUSSEN, S.; THOR, J.; Fire engineering design of steel structures. Swedish Institute of Steel Construction. Stockholm, 1976

[25] SÃO PAULO (Estado). Decreto $n^{\circ} 56.819$, de 10 de março de 2011. Institui o regulamento de segurança contra incêndio das edificações e áreas de risco no Estado de São Paulo e estabelece outras providências. Diário Oficial do Estado de São Paulo, São Paulo, p 1-11. 11 de março de 2011.

[26] SÃO PAULO (Estado). Secretaria de Estado dos Negócios da Segurança Pública. Polícia Militar. Corpo de Bombeiros. Instrução Técnica n. 7: Separação entre edificações (isolamento de risco). São Paulo, 2011.

[27] SÃO PAULO (Estado). Secretaria de Estado dos Negócios da Segurança Pública. Polícia Militar. Corpo de Bombeiros. Instrução Técnica. IT 08. Segurança estrutural nas edificações - resistência ao fogo dos elementos de construção. São Paulo, 2001.

[28] SÃO PAULO (Estado). Secretaria de Estado dos Negócios da Segurança Pública. Polícia Militar. Corpo de Bombeiros. Instrução Técnica. IT 08. Segurança estrutural nas edificações - resistência ao fogo dos elementos de construção. São Paulo 2004.

[29] SÃO PAULO (Estado). Secretaria de Estado dos Negócios da Segurança Pública. Polícia Militar. Corpo de Bombeiros. Instrução Técnica n. 8: Resistência ao fogo dos elementos de construção. São Paulo, 2011.

[30] SÃO PAULO (Estado). Secretaria de Estado dos Negócios da Segurança Pública. Polícia Militar. Corpo de Bombeiros. Instrução Técnica n. 9: Compartimentação horizontal e compartimentação vertical. São Paulo, 2011.

[31] SÃO PAULO (Estado). Secretaria de Estado dos Negócios da Segurança Pública. Polícia Militar. Corpo de Bombeiros. Instrução Técnica n. 14. Carga de Incêndio nas Edificações e Áreas de Risco. Instrução Técnica do Corpo de Bombeiros. São Paulo, 2011.

[32] SOCIÉTÉ SUISSE DES INGÉNIEURS ET DES ARCHITECTES (SIA-81). Evaluation du risque d'incendie. Méthode de calcul. Documentation n81. Zürich.1984.

[32] SOCIÉTÉ SUISSE DES INGÉNIEURS ET DES ARCHITECTES (SIA-81). Evaluation du risque d'incendie. Méthode de calcul. Documentation n81. Zürich.1996.

[33] SCHLEICH, J.-B.; CAJOT, L.-G. Global fire safety concept for buildings. La Revue de Métallurgie - CIT. Vol. 11. EDP Science, Paris, 1997.

[34] SILVA, V. Pignatta. Estruturas de aço em situação de incêndio. Tese de doutorado em Engenharia Civil, Escola Politécnica da Universidade de São Paulo. São Paulo, 1997.

[35] SILVA, V. Pignatta. Estruturas de aço em situação de incêndio. 256 p. Zigurate Editora. São Paulo. 2004.

[36] SILVA, Valdir Pignatta. Sobre o coeficiente gamas1 do método do tempo equivalente para a determinação do tempo requerido de resistência ao fogo das estruturas. Revista Minerva, v. 5, p. 315-321, São Carlos. 2008. 
[37] SILVA, V. Pignatta. Projeto de Estruturas de Concreto em Situação de Incêndio: conforme ABNT NBR 15200:2012. Blucher. São Paulo. 2012

[38] SILVA, Valdir Pignatta. Segurança Contra Incêndio em Edifícios - Considerações para o Projeto de Arquitetura. Blucher. v. 1. 129p. São Paulo. 2014.

[39] THOMAS, G.C., BUCHANAN, A.N., FLEISCHMANN, C.M. Structural Fire Design: The Role of Time Equivalence. In: Proceedings of The Fifth International Symposium, Christchurch, 1997.

[40] VARGAS, Mauri Resende ; SILVA, Valdir Pignatta . Resistência ao fogo das estruturas de aço. Centro Brasileiro da Construção em Aço - CBCA. v. 1. 76p. Rio de Janeiro: 2005.

\section{Nomenclature}

$A_{f}-$ floor area of the fire compartment

$A_{t}$ - total area of enclosure (walls, ceiling and floor, including openings)

$A_{h}$ - total area of horizontal openings in roof of compartment

$A_{v}$ - total area of vertical openings of compartment (windows, doors) for the outside

c - specific heat of the compartment element

$\mathrm{h}-$ fire height of the building

$h_{m}$ - weighted average of window heights on all walls

$\mathrm{H}$ - height of the fire compartment

$\mathrm{K}$ - correction factor related to the thermal property of the compartmentation element

$\mathrm{M}$ - correction factor function of the material composing structural cross-sections

$\mathrm{q}_{\mathrm{f}, \mathrm{k}}$ or $\mathrm{q}_{\mathrm{fi}}$ - characteristic value of the fire load density per unit floor area

$\mathrm{q}_{\mathrm{fi}, \mathrm{d}}$ - design value of the fire load density per unit floor area

$\mathrm{q}_{\mathrm{w}}-$ fire load density per unit floor area in $\mathrm{kg}$ of equivalent wood

$\mathrm{t}_{\mathrm{e}}$ - equivalent time

W - ventilation factor

$\gamma_{s 1}$ - factor taking into account the fire activation risk due to the type of occupancy

$\gamma_{\mathrm{s} 2}$ - factor taking into account the fire activation risk due to the size of the compartment and the high of the building

$\gamma_{n}$ - factor taking into account the different active firefighting measures

$\lambda$ - thermal conductivity of the compartmentation element

$\rho$ - density of the compartmentation element 